\title{
THE EVOLUTION OF A FEMININE STEREOTYPE: WHAT TINKER BELL TEACHES CHILDREN ABOUT GENDER ROLES
}

\section{Suneé Jones}

Department of English

University of Pretoria

suneejones@gmail.com

\section{ABSTRACT}

Research has shown that some children's stories may contain subversive cultural messages and that, by consuming them, children are unconsciously socialised and unwittingly influenced to accept cultural norms relating to, among other things, gender roles, race relations, power structures and class distinctions. This process of socialisation is especially effective through the medium of children's literature, especially those stories that make use of generic elements such as the archetypes found in fairy tales, and the fairy tales re-imagined and produced as films by the Walt Disney Company. A literature review confirms that gendered messages are present in the entertainment provided to children and highlights the most universal preconceptions of feminine roles in Western society. To determine if these gender stereotypes have evolved in recent years, the depiction of a beloved children's character, the fairy Tinker Bell, first imagined by author J.M. Barrie and later refashioned by Disney to become part of our collective imagination, is explored. A close analysis reviews the depiction of Tinker Bell in three different texts: Barrie's 1911 novel, Peter Pan, Disney's 1953 animated classic of the same name, and the first instalment of Disney's more recent series of movies in the Fairies franchise, Tinker Bell (2008). The results indicate that the original Tinker Bell is a nontraditional female portrayed as a negative stereotype, but that the latest version of Tinker Bell is a non-traditional female portrayed in a positive manner. This shift in emphasis may indicate that gender stereotypes in the $21^{\text {st }}$ century are consciously being reviewed.

\section{UNISA}


Keywords: children's literature, Disney, feminist cultural analysis, femme fatale, gender roles, gender stereotypes, Peter Pan, socialisation, Tinker Bell

When I was young, Peter Pan was one of my favourite children's stories. Now that I am an adult, it remains one of my favourite books.

- Michael Hague, illustrator of the $100^{\text {th }}$ anniversary edition (Barrie 2003, 159)

Peter Pan is arguably one of the most beloved, and well-known, children's stories. Originally entitled Peter and Wendy, author J.M. Barrie's novel, which Rose (1984, 5) maintains never had children as its intended audience, has nevertheless shaped the imagination of countless children since it was first published in 1911. The boy who never grows up, his arch-nemesis Captain Hook, the maternal Wendy, and Peter's constant companion, Tinker Bell, have become part of our collective imagination. While the story might seem to be only an amusing adventure tale on the surface, there are in fact many social issues to be explored within its pages - most especially, for the purposes of this article, in the representation of the character of Tinker Bell.

Drawing on feminist theory, this article provides a close analysis of Tinker Bell's portrayal and scrutinises her introduction as a supporting character in Barrie's original text through to her present status as a main protagonist in Disney's Fairies franchise. The article then evaluates the differences in these portrayals and considers what gender lessons might be conveyed to children by these depictions.

Barrie's original Tinker Bell is an aggressive, vain, snobbish and foul-mouthed little fairy, who is involved in a complicated relationship with the title character, Peter Pan. If Wendy is the epitome of the perfect early $20^{\text {th }}$-century woman in a patriarchal society, as will be discussed later, then Tinker Bell is her antithesis and this article will explore her stereotypical portrayal as the evil Other of a Victorian consciousness. The portrayal of Tinker Bell and Wendy's characters in the Walt Disney Company's 1953 animated classic, Peter Pan, aimed unequivocally at a younger audience, presents the same opposition, albeit within a different social context. This article contends that the aim of these representations remains the same, which is to indicate ideal and accepted feminine behaviour. However, as will be discussed later, the first instalment in the recent series of Tinker Bell films from the Walt Disney Company, Tinker Bell (2008), has a different agenda. In this film, Tinker Bell has evolved to become a role model for a new kind of femininity for little girls.

This article is based on and explores the hypotheses that children's stories may contain subversive messages related to gender roles that influence children's worldviews, that the original Tinker Bell is a non-traditional female portrayed as a negative stereotype, and that the new Tinker Bell is a non-traditional female portrayed in a positive manner.

To substantiate these hypotheses, I will first review the literature and discuss the theoretical background in relation to the origin and criticism of fairy tales, which, as Zipes $(2011,29)$ attests, formed the basis of the development of modern ${ }^{1}$ children's 
literature. I will then aim to demonstrate that gender ideology is embedded in children's literature and cultural products, and that children internalise this ideology through immersion. I will also argue that the media, especially Disney films, are just as effective in indoctrinating children with contemporary ideology while masquerading as innocuous entertainment. This article then aims to uncover the dimensions of gender ideology present in the book and subsequent films through content analysis. The ultimate aim is to prove that the portrayal of Tinker Bell in the new series of films has significantly developed away from her introduction in Barrie's novel, finally freeing her from negative gender stereotyping.

Although fairy tales and children's literature are two very distinct theoretical subjects, it is important to note that children's literature evolved in the $19^{\text {th }}$ century from the literary fairy tales of the $17^{\text {th }}$ and $18^{\text {th }}$ centuries (Zipes 2011,29), and therefore contain many of the 'socialising elements' (ibid, 34) of the fairy tale genre. It is therefore necessary to first consider the impact that this origin may have had on children's literature.

Fairy tales were not initially intended for children (Zipes 1994, 23). As a genre, they have their roots in the oral storytelling tradition 'created and cultivated by adults (Zipes 2011,3 ) as a 'dialogue on values and manners' (ibid, 10). These stories later formed the basis of the literary fairy tales created in the $17^{\text {th }}$ century as ideological tales with which to express views on the 'civilising process' (Zipes 1994, 26). From their conception, fairy tales have therefore had a hidden agenda and have been used to convey subversive messages that confirm the beliefs of a specific sociocultural ideology.

It was only much later, in the early $18^{\text {th }}$ century, when more European writers (and most notably the Brothers Grimm) started writing specifically for children, that fairy tales were used to 'provide models of behaviour for the rearing and schooling of upperclass children' (Zipes 2012,29). Even the Brothers Grimm did not originally intend their stories to be read by younger audiences (Zipes 2011, 60). Their tales were collected to preserve German poetry and mythology, and only after intensive censorship, in which the stories were made 'more pure, truthful, and just', were they considered not 'harmful for children's eyes' (ibid.).

According to Zipes (cited in Bell, Haas and Sell 1995, 26), by the end of the $19^{\text {th }}$ century the literary fairy tale was readily available in printed form (giving it greater legitimacy than oral form) to an elite few who were able to read the tales at their leisure. They were often read by parents to children. Zipes (cited in Bell et al. 1995, 25) declares that the 'fairy tales for children were sanitised and expurgated versions of the fairy tales for adults' and that they were constantly checked to ensure that they maintained an 'ideology of harmlessness', although they were constructed to 'reinforce the dominant social codes within the home and school' (Zipes 2011, 34). Eventually, these social codes became part of what Jung (in Stevens 1982, 39) called the 'collective unconsciousness' in which 'communities reward conformity to group norms and punish deviance' (ibid, 238). As a result, certain archetypes ${ }^{2}$ or gender stereotypes became a 
prevalent characteristic of fairy tales that, when presented to children, may influence their view of gender roles in Western society.

Zipes $(2011,175)$ states that children between the ages of five and ten are the primary audiences of fairy tales these days. It is during this early stage of development, when children's conceptions of the world are formed (Trepanier-Street and Romatowski 1999, 155), that they are most susceptible to the subversive cultural messages (Zipes $2011,5)$ conveyed through fairy tales. Tatar $(1987,33)$ defines fairy tales as "narratives set in a fictional world where preternatural events and supernatural intervention are taken wholly for granted'. This definition can be applied to a broad range of children's literature, including Peter Pan.

Tsao $(2008,109)$ confirms that the books children read (or that are read to them) 'play a significant part in transmitting society's culture'. Children's stories may be set in fanciful places and be populated by imaginary creatures, but they contain life lessons that are very real and applicable to the 'real world' (Diekman and Murnen 2004, 373). Taylor $(2009,6-7)$ further emphasises the role of cultural symbols contained in books, noting that 'children's books present a microcosm of ideologies, values, and beliefs from the dominant culture... [and books are] an important mechanism through which culture is transmitted from one generation to the next'. Giroux $(1994,65)$ goes so far as to assert that popular culture forms the basis of children's education, most notably in the fairy tales produced by the Walt Disney Company.

Children read and watch stories without realising that they are being influenced into accepting certain beliefs and values. Incidentally, it is interesting to note that, in many cases, these beliefs and values do not even necessarily coincide with those of the child's own culture, but are often American or British in origin, as is the case with the film adaptations produced by the Walt Disney Company and distributed globally.

Through the re-imagining of classic tales, children are unwittingly influenced into accepting cultural norms relating to, among other things, gender roles, race relations, power structures and class distinctions. This process of socialisation happens unconsciously, which means that children, while being entertained, are simultaneously receiving cues as to how to behave, what to value, what ideals to strive for and how to go about attaining those ideals. These seemingly 'harmless' (Zipes 2011, 56) fairy tales may have a much more significant impact on a child's worldview than many people realise.

Diekman and Murnen $(2004,373)$ observe that the written word 'exerts such a powerful persuasion [that it has] been found to produce changes in adults' beliefs and attitudes, even when passages are clearly based in fiction'. The higher the degree of immersion experienced by the reader, the more persuasive the effects of the story, and as Diekman and Murnen (ibid.) rightly conclude, 'such immersion is likely to be more pronounced for children than for adults'. Once children find themselves immersed in a story, they are unlikely to realise that they are being taught subtle lessons, and that their worldview is unwittingly defined for them. 
One of the most intrinsic ideologies encoded into children's stories is the matter of gender socialisation (Narahara 1998, 13). Gender portrayal 'contributes to the image children develop of their own role and that of their gender in society' (Singh 1998, 2). Singh (ibid, 3) further asserts that the

manner in which genders are represented in children's literature impacts children's attitudes and perceptions of gender-appropriate behaviour in society. Sexism in literature can be so insidious that it quietly conditions boys and girls to accept the way they 'see and read the world', thus reinforcing gender images.

Children unconsciously learn the "cultural trends in the relative value placed upon men and women' (Clark et al. 2003, 440) from stories, and their understanding of themselves as gendered beings are shaped by this encounter.

This is even more valid in today's media-rich society, where 'the individual and collective identities of children are largely shaped politically and pedagogically in the popular visual culture of video games, television [and] film' (Giroux 1994, 65). England, Descartes and Collier-Meek $(2011,557)$ note that the constructivist approach and cultivation theory both suggest that children's 'cognitive understanding of gender' is strongly impacted by the media, and the messages the media contain, to which they are regularly exposed. One of the major influences is the films produced by the Walt Disney Company (Brode 2005, 268).

Zipes $(2011,196)$ attests that it is Disney ${ }^{3}$ which 'truly revolutionised the fairy tale as institution through the cinema'. Through the 'artful use of images' (ibid, 198), Disney deprives the audience of 'visualising their own characters, roles and desires' (ibid.) and manipulates them into accepting the film's message about 'proper sex roles, behaviour, manners, and customs' (ibid, 204). As Dines (Brode 2005, 5) points out, it is important to understand how the media influence consumers through the 'wide array of image stereotypes ... about race and class and gender' with which they are constantly inundated. Disney may be the most subversive of all Hollywood entertainers, Brode (ibid, 270) asserts, 'providing [a] form of easily accessible popular culture ... to impressionable mainstream children'. When observing his own children, Giroux (1994, 66) noticed that

[Disney films] inspire at least as much cultural authority and legitimacy for teaching specific roles, values and ideals than more traditional sites of learning such as public schools, religious institutions, and the family. Disney films combine an ideology of enchantment and aura of innocence in narrating stories that help children understand who they are, what societies are about, and what it means to construct a world of play and fantasy in an adult environment.

It is therefore possible to argue that children learn more about social norms and values from popular films, such as those produced by the Walt Disney Company, than they do from traditional institutions, such as the school or church.

Giroux (ibid.) further explains that 'the cultural authority of this postmodern mediascape rests on its power to usurp traditional sites of learning and its ability to expand 
the power of culture through an endless stream of signifying practices that prioritise the pleasures of the image over the intellectual demands of critical enquiry'. Parents allow their children to watch Disney movies for entertainment value, believing that the images and stories presented are harmless and do not need further analysis (England et al. 2011, 557). In fact, Bell et al. $(1995,4)$ note that many people are 'extremely resistant to critique of Disney film[s]', believing them to be " "pure entertainment", somehow centrifuged from ideological forces'. Sun $(2004,52)$ also points out that children are exposed to Disney films at a very young age and tend to watch their favourites repeatedly, until the attachment intensifies to such a point that they are unwilling to view the film in any critical manner. However, since young children learn social values from the stories in which they immerse themselves (Tatar 1987, xv), whether in written or visual format, it is vital to consider what it is, exactly, that they are learning.

Diekman and Murnen $(2004,375)$ declare that the stereotypical portrayal of characters is one of the most frequently explored aspects of children's literature. Sexism usually manifests in the 'idealisation of women's traditional roles' or in the portrayal of female characters in 'overly romantic terms or as delicate creatures who require protection'. Furthermore, female characters are often depicted as 'dependent, emotional, silly, clumsy, and lacking intelligence ... passive, gentle, domestic, motherly, and unassertive' (Tsao 2008, 110), while male characters are associated with competence, achievement, cleverness, adventure and active mastery (ibid.). Additionally, female characters are often victimised (ibid, 111) and need to be rescued. Singh $(1998,2)$ also finds gender stereotypes to be prevalent in children's literature, noting that

girls [are portrayed] as acted upon rather than active. Girls are represented as sweet, naive, conforming, and dependent, while boys are typically described as strong, adventurous, independent, and capable. Boys tend to have roles as fighters, adventurers and rescuers, while girls in their passive role tend to be caretakers, mothers, princesses in need of rescuing, and characters that support the male figure. Often, girl characters achieve their goals because others help them, whereas boys do so because they demonstrate ingenuity and/or perseverance. If females are initially represented as active and assertive, they are often portrayed in a passive light toward the end of the story.

Singh (ibid, 3) concludes that both genders are constrained by these stereotypes. Just as boys are pressurised into 'gender appropriate' roles that rarely allow for emotional demonstration, girls learn that they must be content with passive roles. These stereotypes are not a new phenomenon and have been carried through from previous historical periods, as Talairach-Vielmas (2007) avers in her study of Victorian novels, noting that 'the use of fairy tales was widespread in Victorian fiction ..., nearly all Victorian novelists alluded to fairy worlds. Fairy tale motifs enabled writers to enhance their heroines' beauty, and above all to encode a patriarchal ideology' (Talairach-Vielmas 2007, 1).

The stereotypical depiction of gender roles is not limited to the written word. Giroux $(1994,71)$ notes that the "construction of gender identity for girls and women 
represents one of the most controversial issues in Disney's animated films'. In their analysis of the Disney princesses, England et al. $(2011,565)$ found that the lead female characters were frequently portrayed as 'idealised feminine figures' - skilled in nurturing and conventionally beautiful - and through compliance with the gendered system were rewarded by the end of the film's happy conclusion with a gain in social power and wealth. We can consider Disney's 1937 feature film, Snow White and the Seven Dwarfs, as an example. Snow White is a neglected princess forced to work as a scullery maid and sent to her death for being fairer than the evil queen, before taking up residence as a housekeeper for seven (male) dwarfs. When she is in need of rescue, a prince, whom she has only met briefly once before, sweeps her up in his arms and rides off with her into the sunset towards a castle in the clouds, while the chorus sings of wedding bells and the movie concludes with the promise: ' $\ldots$ and they lived happily ever after ...', the objective of all romantic ${ }^{4}$ fiction. Snow White is portrayed as the ideal woman: hardworking, nurturing and beautiful, and for this she is rewarded with a gallant man who rescues her from servitude and makes her his queen. As England et al. (ibid.) affirm, these 'strongly gendered messages help to reinforce the desirability of traditional gender conformity'.

In Linton's essays, The girl of the period, published in 1883, she condemns liberated womanhood in favour of the domestically grounded ideal that characterised the Victorian woman, that of a 'tender, loving, retiring [and] domestic' (Linton 1883, 6) woman. Virginia Woolf (1931, loc. 3008-3012), referring to Coventry Patmore's 1854 narrative poem The Angel in the House, eloquently explains what was expected of women in the early $20^{\text {th }}$ century:

She was intensely sympathetic. She was immensely charming. She was utterly unselfish. She excelled in the difficult arts of family life. She sacrificed herself daily. If there was chicken, she took the leg; if there was a draught she sat in it - in short she was so constituted that she never had a mind or a wish of her own, but preferred to sympathise always with the minds and wishes of others. Above all - I need not say it - she was pure. Her purity was supposed to be her chief beauty - her blushes, her great grace.

In J.M. Barrie's 1911 novel, Peter Pan, Wendy is a perfect Victorian woman in the terms outlined by Woolf. She acts as housewife to Peter and mother to the Lost Boys (Barrie $2003,91)$. She is content in the house built especially for her, where she cares for her little make-belief household by cooking and sewing (p. 66), administering medicine (p. 103) and telling bedtime stories (p. 97). She is described as charming (p. 23) and ladylike (p. 25), vulnerable (p. 42) and in need of Peter's protection (p. 81). Wendy is depicted as a patriarchal Victorian society's ideal woman.

Venturino $(2013,157)$ maintains that "every "good" female image in literature ... is likely to be accompanied by an explicitly negative image that inverts the idealised stereotypes and perpetuates images of women who are monstrous, unfeminine, dangerous, and out of control'. If it is agreed that Wendy is the idealised stereotype in 
Barrie's Peter Pan, then, through the course of the narrative, it soon becomes clear that Tinker Bell is the antithesis of Linton's ideal.

The first mention of Tinker Bell in Barrie's novel is of a 'strange light, no bigger than your fist' (p. 9) accompanying Peter Pan into the Darling nursery. The light flashes about, then comes to rest revealing a tiny girl 'exquisitely gowned in a skeleton leaf, cut low and square, through which her figure could be seen to the best advantage. She was slightly inclined to be embonpoint' (p. 19).

Tinker Bell is described in such a way as to objectify her. She wears a revealing dress made from a skeleton leaf, which is one that has had the pulpy parts removed, leaving only the fibrous part (The Free Dictionary). For all practical purposes, she is wearing a transparent lace that displays more of the body than it covers, showing her figure to its best advantage and implying that she is vain as well as aware of her own sexuality. She is neither innocent nor pure. The neckline of the dress is low-cut and square, a style that emphasises a woman's chest and that must have been quite scandalous to an audience with the Victorian era's modest sensibilities. Tinker Bell is also described as slightly embonpoint, which can be defined as buxom, chubby, fat or plump (Thesaurus.net). Her figure is rounded and voluptuous and distinguishes her from the child, Wendy, who is simply described as 'in her nightgown' (p. 14).

The kind of excessive flaunting of femininity exhibited by Tinker Bell is aligned with the femme fatale, a creature regarded by men as evil incarnate (Doane 1982, 82). In her study of Victoria literature, Hedgecock $(2008,2)$ considers the femme fatale as a 'literary signpost of the changing roles of women in the nineteenth century'. She notes that the femme fatale was historically considered to possess considerable agency:

[T] he femme fatale is vibrant and courageous ... and very different from her female counterparts such as the idealised domestic woman ... [she] uses her mischief to show the less serious side of life, often laughing at her own foibles.... [But] the image of the femme fatale changes from this rather charming, complex, devious young woman into a one-dimensional, dangerous archetype. Such a shift did not occur by accident, but seemed more a reaction to the increasing demands of middle-class and working-class women for equality. (ibid, xv)

As will be discussed later, Tinker Bell is, in fact, depicted as a working-class woman, one who does not conform to the maternal and domestic ideal. As Doane points out (Bell et al. 1995, 115), '[s]he harbours a threat which is not entirely legible, predictable, or manageable'.

Tinker Bell is a tiny creature, which implies that she is weak and easily overpowered, even by something as simple as a child denying the existence of fairies (p. 25). She soon gets locked in a drawer by Peter Pan (p. 19), indicating his (male) power over her, and is unable to escape until he frees her (p. 25).

When Tinker Bell talks it sounds like 'the loveliest tinkle as of golden bells' (p. 19) and only those who understand the fairy language can understand what she says, evidenced by Peter needing to translate for Wendy (p. 25). Without the ability to make herself understood, Tinker Bell is in fact disempowered and dependent on 
a man to convey her words to others. Furthermore, her speech is relegated to pretty, inconsequential sounds that lose all meaning in a cacophony of clanging bells. She is in effect silenced, even when she is 'screaming in fury' (p. 25). To modern audiences, this can be considered an analogy for the silencing of women's voices and/or women's rights, in a patriarchal culture.

Tinker Bell immediately takes a dislike to Wendy, sensing in her a rival for Peter Pan's affections. When Wendy calls her 'lovely' and wishes she were her fairy, Tinker Bell answers 'insolently' and proclaims herself to be Peter's fairy (p. 25). Tinker Bell is jealous and on the offensive, as is evident by her calling Wendy 'a great ugly girl' (p. 25). Her own sense of self-worth is tied closely to Peter's opinion of her, as she subjugates herself to the male gaze (Mulvey 1975, 11), proclaiming her 'his' and eschewing all sense of self-respect or self-regard. Her response to Wendy is arrogant and discourteous. She feels threatened by Wendy, the traditionally acceptable female. When Wendy tries to kiss Peter, Tinker Bell pulls her hair and darts about, 'using offensive language' ( $p$. 26). She behaves in an aggressive manner towards a rival for Peter's affection.

This very behaviour is, ironically, what estranges her from Peter. He responds: 'You know you can't be my fairy, Tink, because I am a gentleman and you are a lady' (p. 25). His meaning is clearly sarcastic, made even more evident by Tinker Bell's response of 'You silly ass' - definitely not what one would expect from a well-bred lady. Because Peter considers himself to be a gentleman, a man of manners and etiquette, he can never be associated with someone as unladylike - vulgar, swearing, hot-headed - as the little fairy. When she flees to the bathroom, presumably to hide her distress, Peter tells Wendy that Tinker Bell is a 'common fairy', one who 'mends the pots and kettles' (p. 25). Not only is her behaviour unworthy of a lady, but the fact that she has a profession, and a lowly one at that, also devalues her in his opinion. One could argue that her representation as a sexual being and her aggressive behaviour associate her with the lower classes, devaluing her even further in the eyes of Barrie's classist Victorian readers.

Even though he considers her 'beneath' him, Peter still feels protective of her, as is proper for a gentleman. On their way to Neverland the children ask Peter to send Tinker Bell away, because her light is drawing the attention of pirates. Peter refuses, saying that Tinker Bell is frightened. 'You don't think I would send her away all by herself when she is frightened!' (p. 40). This earns him a 'loving little pinch' (p. 40). Tinker Bell depends on the male figure to keep her safe, and in return she bestows love on him.

Perhaps the best indication of Tinker Bell's lack of innocence is the scene in which she tries to have Wendy killed. Tinker Bell is an emotional creature, as Barrie (p. 42) explains: 'Tink was not all bad: or rather, she was all bad just now, but on the other hand, sometimes she was all good.' At present, her jealousy is difficult to control. She is ruled by her emotions, bereft of any compassion or regard for human life, amoral to such an extent that she is willing to resort to murder. Trusting and naive, Wendy 'did not yet know that Tink hated her with the fierce hatred of a very woman' (p. 42). Tinker 
Bell personifies the evil feminine ${ }^{5}$ (Nodding 1989, 58) who is dangerous and will stop at nothing to remove the threat that stands between her and her man. When her plan fails, we see Tinker Bell crying, again overcome by emotion, because 'the Wendy lives' ( $p$. 57).

As initiator of the action when using the Lost Boys to shoot Wendy down from the sky, she becomes the femme fatale again, for surely had any of them been successful in killing Wendy they would have been destroyed (or banished, at the very least) by Peter. It is also interesting that the narrator specifically warns Tootles, the kindest and humblest of the boys, against Tinker Bell (p. 45). She uses the boys' loyalty to their leader for her own evil purposes. Once Wendy has fallen to the ground, apparently dead, Tinker Bell hides (p. 55), knowing that what was done was wrong, but unwilling to take responsibility for it.

When Peter learns of Tinker Bell's actions, he banishes her from his presence. No matter how much Tinker Bell pleads with Peter, he does not relent. It is only after Wendy intervenes - as one would expect from a sensitive and nurturing female (England et al. 2011, 560) - that he shortens the punishment to a week (p. 57). Clearly Peter does not hold Tinker Bell in as high regard as she does him. He will not be swayed by her persistence and she is dependent on his goodwill to be allowed to return to his side. Her emotional attachment makes her dependent on the man.

Eventually she does return, and risks her own life to save Peter's. Simone de Beauvoir (in Tong 1989, 206) posits that men idolise self-sacrificial women. However, this would not seem to be the case with Peter. In the novel's concluding chapter, when he goes to visit Wendy in London, Peter no longer remembers the fairy. He casually remarks: 'There is such a lot of them ... I expect she is no more' (p. 149). Although Tinker Bell's whole existence centres around the male character, he returns to Wendy instead, and barely acknowledges Tinker Bell, nor does he concern himself with whether she is still alive or not.

In Barrie's novel, Tinker Bell is the antithesis of Wendy, who fulfils the role of the perfect Victorian woman. Tinker Bell is depicted as sexual, aggressive, vulgar, badmannered and emotional. All these negative traits conspire to make of her the femme fatale that men fear. Her reward is to be utterly forgotten by the object of her infatuation, Peter, who returns to Wendy year after year. Tinker Bell's character teaches children that women who share these traits, who are overtly sexual and cannot control their emotions, are inherently evil and are doomed to a life of disappointment and abandonment.

At first it may seem as though Disney's Peter Pan stays true to the original novel, but there are various subtle differences in Tinker Bell's character in the 1953 film. Clark et al. $(2003,440)$ note that 'the 1950 s were a time when traditional gender roles prevailed in the larger society'. These stereotypes are reflected in Betty Friedan's The feminine mystique (1963), which outlines post-Second World War expectations of American women to stay at home and confine their interests to their homes and families. These norms are quite visible in both Wendy and Tinker Bell. 
Much like the novel, we first meet Tinker Bell when she accompanies Peter Pan to the Darling nursery. She is still a bright light that darts about the room and when she speaks one hears nothing but the tinkle of tiny bells. Barrie provided his readers with Tinker Bell's words in the novel, although filtered through Peter's interpretation of them, yet Disney decided to leave her unintelligible to the audience - perhaps because Disney's patriarchal values (Zipes 1994, 202) preferred to undermine a non-traditional female character with silence, while the more traditional female chatters on incessantly.

Similar to Barrie's description, the animated Tinker Bell is a tiny, blonde girl with a voluptuous hourglass figure wearing an extremely short (although thankfully not transparent) green dress with a plunging neckline. Brode $(2005,129)$ notes that the 1950 s blonde was a woman 'morally flawed, inwardly troubled, yet inherently decent', but although blondes were preferred before marriage (or as mistresses), it was still the brunette, 'conservative, traditional, respectable', who remained the 'icon of marriageable material'. It is therefore noteworthy that, in Disney's visual representation of Wendy, she is, not coincidentally, a brunette.

Tinker Bell's image is overtly sexual. She is still a vain little creature who smiles at herself in the mirror, running her hands across her body in a suggestive way. One can easily believe, as Brode (ibid, 133) reports, that Disney animators used nude photographs of Marilyn Monroe as her model. She seems to be particularly distracted by the size of her hips, clearly a sign as Bartky $(1990,100)$ would point out, of the cultural obsession with the perfect female body. Simone de Beauvoir (in Tong 1989, 209) would call her a narcissist, a woman who can only feel self-fulfilled through the perfection of her body. She becomes the object of male desire and the male gaze as she is 'enchained by the need to please man' (ibid.).

Perhaps to contain her sexuality, Tinker Bell is often depicted as clumsy or silly. She is locked in the drawer and tries to escape through the keyhole. However, her hips are too large to fit through, revealing her underwear repeatedly as she struggles to free herself. This display is presumably cute and aimed at younger viewers who would find it funny, but actually fetishises (Kaplan 2000,31) the female form.

Unlike in the novel, Tinker Bell in the film shows some initiative in trying to escape from the drawer by using various implements to open it. She is motivated by her anxiety over Wendy starting to offer Peter Pan kisses and manages to free herself in time to pull Wendy away from Peter by her hair. Although it is significant that Tinker Bell no longer needs Peter to rescue her, it is still jealousy that motivates Tinker Bell's release. She is still depicted as being controlled by her emotions.

The objectification and diminishment of Tinker Bell continue when the children learn to fly. Tinker Bell, unwilling to give them the dust that will enable flight, flees, but is grabbed by Peter and paddled on the bottom to sprinkle the children with dust. Against her will, Tinker Bell is subjected to what can be construed as a cleverly disguised rape scene. Is it any wonder that she shoots off as soon as Peter releases her? Wendy is never treated in a similar manner by any of the male characters, yet not long after Michael (the 
youngest boy) also grabs the fairy and shakes her vigorously up and down, dumping fairy dust on the dog's posterior. Unlike Wendy, the conforming female who accepts her role in patriarchal society, Tinker Bell is repeatedly subjected to the male will.

Of course, none of the male characters are portrayed as doing anything wrong, and Tinker Bell has no one to vent her frustration on but Wendy. This might indicate the infallibility and unquestionable power of the patriarchal order. Tinker Bell finds Wendy's compliance with such an order a threat, and attacks Wendy as symbolic of that threat. This aggression culminates in the attempted murder scene. Wendy is saved by Peter and we see Tinker Bell flying off in frustration and rage, engulfed by a red glow, burning leaves as she passes through them. Her emotions are on the rampage, she is dangerous and out of control (Venturino 2013, 157) and therefore, in other words, uncontrollable.

At first, Tinker Bell tries to evade responsibility for the shooting, but when Peter confronts her, she admits her guilt and tries to use her sexual allure - swaying her hips suggestively - to escape punishment. Her behaviour reinforces the stereotype of women as untrustworthy and sexually manipulative. She tries to use her 'Otherness' to personal advantage (Tong 1989, 209) as the femme fatale does. However, Peter is not fooled and banishes her from his presence, once again demonstrating man's power over woman in a patriarchal order.

When next we see Tinker Bell, she has been captured by Smee and has been brought to Captain Hook. She is in tears, crying over Peter's preference for Wendy. Hook convinces the fairy that Peter is not to blame, that it is Wendy's fault that Tinker Bell has been 'cast aside like an old glove' and offers to kidnap Wendy so that Peter can forget about his 'mad infatuation' (Peter Pan 1953). He tricks Tinker Bell into revealing the boys' hideout before locking her up in a lantern. Not only does this scene reiterate Tinker Bell's obsession with Peter, but Disney also plays on a number of traditional feminine stereotypes, namely that women are emotional and often collapse in tears, that they are unintelligent and easily fooled, that they are physically weak and victimised (England et al. 2011, 560) and, most importantly, that they are dependent on masculine validation.

When she hears of the bomb Hook leaves for Peter, Tinker Bell manages to free herself and rushes off to rescue the boy, showing the traditional male characteristics of being the initiator of the action and bravery (ibid, 558). She reaches Peter in time, but the bomb explodes in his face, yet he survives unscathed and she is trapped under a mound of rubble. Her brief spell of male positive action is undermined by womanly physical weakness (ibid, 559) and she needs to be rescued by Peter.

In response to this display of devotion from Peter, it is as if Tinker Bell turns over a new leaf. She tries to convince Peter that he must go to Wendy and the boys' aid first, thereby redeeming herself by showing compassion for others. Peter responds positively and declares that she 'means more to [him] than anything in this whole world'. Tinker Bell now lives up to the expectation of the flawed, but inherently good female (Brode 
2005, 129). Her redemption is rewarded: at the end of the film, we see Tinker Bell willingly covering the pirate's ship in pixie dust and are left with the impression that she stays by Peter's side while his adventures continue.

In this film, Tinker Bell is depicted as the feminine Other, a sexually attractive creature who is willing to use her sexuality for her own ends and to the detriment of others. However, she is punished for this behaviour by having her sexuality limited through male dominance. When she cannot control her emotions, she brings harm to herself and others. In this way she conforms to the stereotype of women as being at the mercy of their emotions, and thus irrational. It is only once she exhibits the traditional feminine traits of compassion and submission that she is rewarded. Her character teaches children that feminine sexuality is dangerous, especially when abused, but that good behaviour will result in a happy ending.

In the new series of Tinker Bell films, the little fairy still displays many of her old characteristics, but they are no longer presented in a negative light. These changes in her portrayal reflect the 'changing gender roles and expectations in American society' (England et al. 2011, 563) in recent years.

When we first encounter Tinker Bell in Disney's 2008 film, Tinker Bell, she has just been birthed from a baby's first laugh. She has shoulder-length blonde hair and is wearing a white dress, which symbolises innocence, perfection (Heller 2000, 130), purity and chastity (Varichon 2000,16). Wearing white also signifies that she is good, reversing her stereotypical image away from the evil femme fatale. She appears timid and shy as she finds herself the centre of attention of a group of fairies who have come to welcome the new arrival. In effect, Tinker Bell's image is recreated here. Gone is the sexual, amoral and aggressive little creature and in her place we see a modest newborn.

Queen Clarion explains that Tinker Bell needs to find her talent, to determine where she belongs. She first chooses a flower, but it wilts at her touch. She then walks from symbol to symbol, and passes by a hammer. The hammer starts glowing brightly, indicating that she has a talent for tinkering. Other fairies remark that they have never seen anyone with such a strong and rare talent. Already we learn that Tinker Bell is nontraditional - she has no talent for nurturing, but is rather suited to physical, intelligent, rational and traditionally male work, even though it was not the talent she would have chosen for herself. This implies that little girls may not be able to choose what they are good at, but they are still special and should be content with their skills and abilities. They are also no longer limited to traditionally female professions and are not condemned for showing an interest in more male-dominated activities.

Tinker Bell is initially disappointed when she meets the oafs, Clank and Bubble, and realises the company she will keep as a member of the tinker fairies. At first she seems intimidated by the two boys, but then tentatively declares herself happy to meet them. She is their equal, no longer submissive to male dominance. She also no longer feels the need for validation in their eyes, because she is not threatened by other females. 
In fact, she easily makes friends with a group of four other female fairies. She shows no aggression towards them, but instead tries to learn from them.

There is still a hint of Tinker Bell as the sexual object, the need for females to be petite and pretty, to still be obsessed with appearances (Tsao 2008, 110), as all female characters in Disney movies typically are. The first thing Tinker Bell does when assigned her own house, is to try on the dresses in her wardrobe. They are much too big for her, and she looks in the mirror, not pleased with what she sees. So she modifies the clothes to fit her. When next we see her, her long shapely legs move into the shot. The camera pans up her legs to the short skirt, up her hourglass figure, past the plunging neckline to a face that is now enhanced by her long blonde tresses being tied up on top of her head. She smiles coyly when she notices Clank and Bubble's reaction, which is to stare in amazement, Bubble saying dazedly: 'So ... pretty' as the lenses in his glasses pop out. It is interesting to consider why Disney felt the need to include this scene when the rest of the film goes to so much trouble to indicate that Tinker Bell should be judged by her skills and intelligence. It can be argued that an independent, intelligent female is still less threatening when she is preoccupied with pleasing the male gaze.

Another traditional stereotype still attached to Tinker Bell is that of being small, and therefore weak. Clank points out that she is tinier than expected and Fairy Mary notes her 'dainty' (Tinker Bell 2008) hands. However, Fairy Mary also promises that her small hands will not be a problem and that she will soon build 'tinker muscles' (Tinker Bell 2008). Clearly, little girls should not let their physiques or femininity constrain them if they want to take up traditionally male professions.

The plot is dedicated to teaching the lesson of being true to yourself. Upon learning that tinker fairies are not allowed to travel to the mainland, Tinker Bell eschews her natural talent and tries to learn other skills, with disastrous consequences. When she is singlehandedly responsible for delaying the coming of Spring (a responsibility she immediately takes upon herself, unlike her previous incarnations), she reverts back to what she is good at: tinkering. She designs and builds many marvellous contraptions, which enable the fairies to repair all the damage she has done. Tinker Bell shows intelligence, logic, bravery, ingenuity and an ability to work with others to reach her goals. She is rewarded by being allowed to travel to the mainland.

The last vestiges of the old, malevolent feminine stereotype are removed on the mainland, when Tinker Bell returns a music box which she had repaired to a little girl in London. The girl happens to be Wendy Darling. In returning the toy to her once archnemesis, the slate is rubbed clean. There is no longer any enmity between Tinker Bell and Wendy, effectively removing their negative history and leaving the future bright with possibilities.

As yet it is unclear whether Disney intends the series of new Tinker Bell films to act as a prequel to the Peter Pan film. If that is the case, it will be interesting to see if Tinker Bell's depiction changes for the worse as she once again becomes Peter's Tink (p. 25). 
Both the literature review and the analysis of the portrayal of Tinker Bell in the original novel and subsequent Disney movies confirm that fairy tales and children's literature convey ideological lessons regarding, amongst other things, gender roles. The constructivist approach and cultivation theory suggest that children are influenced by gendered stereotyped depictions through exposure to media content (England et al. 2011, 557). As Karriker (2002, 142-143) warns, 'the media, specifically films, do not merely reflect that actual society, but create one of their own - a society with unique values, stereotypes, and expectations that can be made to seem as authentic or even more authentic than reality'. It is safe to assume that children are affected by the stories they read (or that are read to them) and the animated films that they frequently watch.

As demonstrated, Tinker Bell was not conceived as the benign and innocent little creature we know today. She served as an example to Victorian children of the evil Other, the feminine that is out of control. Her contrast with Wendy indicated unacceptable behaviour for the women of that time, and she was duly rewarded by losing all that is important to her and dying alone and forgotten. The 1950s version, although made slightly more acceptable for younger audiences, clearly shows that the non-traditional female is still not tolerated. In fact, she is sexually abused and dominated by men, and it is only through redemption gained by embracing more traditional feminine characteristics that she acquires her happily-ever-after.

In contrast, the latest version of Tinker Bell has become a role model for little girls. Gone are the femme fatale, the overt sexuality and the willingness to kill. Instead, we find a girl who is still characterised by non-traditional traits, more male than stereotypically female, and who is now portrayed in a positive light. The message is clear: gender stereotypes in the $21^{\text {st }}$ century are being reviewed. No longer are women confined to nurturing roles, but they are allowed to excel at logical, intelligent and physical activities. Children are learning that gender should not dictate who you are and what you can do. Defiant female characters are being embraced by the media. ${ }^{6}$ It is encouraging to note that their actions are considered acceptable and that their reception is becoming ever more positive.

\section{NOTES}

1. 'Modern' in this context refers to children's literature from the $19^{\text {th }}$ century onwards.

2. Jung (in Stevens 1982, 39) defines archetypes as 'active, living dispositions ... that preform and continually influence our thoughts and feelings and actions'. Examples of such archetypes include the Great Mother (ibid, 89), her inverse the Terrible Mother (ibid, 90) and the Shadow (ibid, 215).

3. All further mentions of Disney refer to the Walt Disney Company, not to its founder, Walt Disney. 
4. As Talairach-Vielmas $(2007,1)$ also points out, 'the conventional happy endings of mainstream literature demanded that the heroines be married and securely locked up'.

5. She can also be considered the Shadow of the Great Mother in Jungian archetypes, a figure who is generally regarded as disreputable or inferior (Stevens 1982, 215).

6. Consider Katniss Everdeen from The Hunger Games and Tris Prior from the Divergent series.

\section{REFERENCES}

Barrie, J. M. 2003. Peter Pan. New York: Henry Holt and Company.

Bartky, S. L. 1990. Femininity and domination: Studies in phenomenology of oppression. Oxon: Routledge.

Bell, E., L. Haas and L. Sell, eds. 1995. From mouse to mermaid: The politics of film, gender and culture. Bloomington: Indiana University Press.

Brode, D. 2005. Multiculturalism and the mouse: Race and sex in Disney entertainment. Austin: University of Texas Press.

Clark, R., J. Guilmain, P. K. Saucier and J. Tavarez. 2003. Two steps forward, one step back: The presence of female characters and gender stereotyping in award-winning picture books between the 1930s and the 1960s. Sex Roles 49(9/10) (November): 439-449.

Diekman, A. and S. Murnen. 2004. Learning to be little women and little men: The inequitable gender equality of non-sexist children's literature. Sex Roles 50(5/6) (March): 373-385.

Doane, M. A. 1982. Film and the masquerade: Theorising the female spectator. Screen 3/4 (Sept/Oct): $74-88$.

England, D. E., L. Descartes and M. Collier-Meek. 2011. Gender role portrayal and the Disney princesses. Sex Roles 64(7): 555-567.

Friedan, B. 1963. The feminine mystique. Harmondsworth: Penguin.

Giroux, H. A. 1994. Animating youth: The Disneyfication of children's culture. Socialist Review 94(3): 65-79.

Hedgecock, J. 2008. The femme fatale in Victorian literature: The danger and the sexual threat. New York: Cambria Press.

Heller, E. 2000. Psychologie de la couleur: Effets et symboliques. Paris: Editions Pyramyd.

Kaplan, E. A. 2000. Women \& film: Both sides of the camera. New York: Routledge.

Karriker, A. H. 2002. Film studies: Women in contemporary world cinema. New York: Peter Lang.

Linton, E. L. 1883. The girl of the period and other social essays. London: Richard Bentley \& Son. http://www.gutenberg.org/files/41735/41735-h/41735-h.htm (accessed June 11, 2015).

Macionis, J. J. 2001. Sociology. 8th ed. Upper Saddle River: Prentice Hall.

Mulvey, L. 1975. Visual pleasure and narrative cinema. Screen 16(3): 6-18.

Narahara, M. 1998. Gender stereotypes in children's picture books. Research report.

Nodding, N. 1989. Women and evil. Berkeley: University of California Press.

Peter Pan. 1953. Film. Walt Disney Studios. USA. 
Rose, J. 1984. The case of Peter Pan, or, the impossibility of children's fiction. London: Macmillan.

Singh, M. 1998. Gender issues in children's literature. Bloomington: ERIC Clearinghouse on Reading, English and Communication.

Snow White and the Seven Dwarfs. 1937. Film. Walt Disney Productions. USA.

Stevens, A. 1982. Archetype: A natural history of the self. London: Routledge \& Kegan Paul.

Sun, C. F. 2004. Staying true to Disney: College students' resistance to criticism of The Little Mermaid. The Communication Review 7(1): 35-55.

Talairach-Vielmas, L. 2007. Moulding the female body in Victorian fairy tales and sensation novels. Aldershot: Ashgate Publishing Ltd.

Tatar, M. 1987. The hard facts of the Grimms'fairy tales. Princeton: Princeton University Press.

Taylor, F. 2009. Content analysis and gender stereotypes in children's books. Sociological Viewpoints 25 (Fall): 5-22.

The Free Dictionary. http://www.thefreedictionary.com/Skeleton+Leaf (accessed October 9, 2013).

Thesaurus.net. http://www.thesaurus.net/embonpoint (accessed April 6, 2015).

Tinker Bell. 2008. DVD. DisneyToon Studios. USA.

Tong, R. 1989. Feminist thought: A comprehensive introduction. London: Routledge.

Trepanier-Street, M. and J. Romatowski. 1999. The influence of children's literature on gender role perceptions: A re-examination. Early Childhood Education Journal 26(3): 155-159.

Tsao, Y. 2008. Gender issues in young children's literature. Reading Improvement 45(3) (Fall): 108114.

Varichon, A. 2000. Couleurs: Pigments et teintures dans les mains des peuples. Paris: Seuil.

Venturino, S. 2013. Literary theory and criticism. New York: Alpha Books.

Woolf, V. 1931. The death of the moth and other essays. Kindle Edition. London: Hogarth Press.

Zipes, J. 1994. Fairy tale as myth, myth as fairy tale. Lexington: University Press of Kentucky.

Zipes, J. 2011. Fairy tales and the art of subversion. 2nd edition. London: Routledge. 